\title{
Bohdan Kravtsiv as a translator of Rainer Maria Rilke's poetry
}

\author{
Alla Paslawska ${ }^{* 1}$ \\ ${ }^{1}$ Ivan Franko National University of Lviv, Universytetska St., 1, 79000 Lviv, Ukraine
}

\begin{abstract}
The paper presents a modified three-level model of possible relations between different cultures proposed by W. Welsh. There have been outlined multicultural, intercultural and transcultural aspects of such relations. The model is exemplified by the translations of Bohdan Kravtsiv. Life circumstances forced Kravtsiv to leave Ukraine and spend his life abroad. He had to work on his translations in different countries and cultures. Just like other cultures influenced his way of thinking, life experience and poetic creativity, due to his political, social, poetic, and translation activities, he himself influenced the cultures he was immersed in and where he was involved in the creative activity. Remoteness from Ukraine did not make the poet and translator break off his relations with his home country. In the Diaspora he did his best to help Ukrainians, replenish the poetic translations of the Ukrainian literature, retain memories of the repressed poets, enrich Ukrainian cultural heritage (transcultural aspect). The language personality of Bohdan Kravtsiv as a translator is considered in terms of his translations of Rainer Maria Rilke's poetry. The structure of the language personality of the translator encompasses verbal, cognitive and pragmatic-motivational levels. The paper focuses on the analysis of Kravtsiv's translations of Rilke's poems into Ukrainian. It has revealed Kravtsiv's brilliant mastery of the poetic word. The translations of Rilke's poems performed by Kravtsiv testify to the translator's efforts to remain faithful to the form and content of the original. In spite of the different morphological and phonetic structures of German and Ukrainian, he succeeded in most cases. The translator's individual style is marked by concise and euphonious translations, multiple new coinages and in-depth knowledge of the original works.
\end{abstract}

\section{Introduction}

Traditionally, literary translation is considered as an art form that requires innate flair. There is an opinion that to prepare a specialist in specialized translation is a difficult but plausible task. It is hardly possible, though, to teach literary translation, as it is the creative activity governed by intuition rather than knowledge acquired while learning. One can argue about the both statements, but there is no doubt that the art of any translation involves a subtle feel for at least two languages, in-depth knowledge of the culture of the native speakers and the material to be translated, and much more that creates a genuine translator.

\footnotetext{
*Corresponding author: alla@mail.lviv.ua
} 
It is difficult to overestimate the role of translations for the development of world culture. After all, "they are an important cultural factor, giving the broad masses the opportunity to get acquainted with the works of the human spirit, which in other countries at different times contributed to the spread of education and raising the general level of culture" [1]. The influence of translated literature on the "mankind's world perception" is generally recognized. There is no need to prove what an important role both artistic and scitech translations play in the formation and elaboration of the norms of a language standard as the main feature of a full-fledged nation [2].

In this respect, it is worth emphasizing the crucial role of translators in the creation of translated literature. Although the number of works devoted to translators has increased in recent decades, their contribution to the creation of world cultural heritage is still underestimated. This is particularly true for the Ukrainian translators who in hard times were forced to emigrate from their home country and work abroad, or stayed in Ukraine, and managed to cultivate the crumbs of freedom tolerated by the totalitarian regimes or fell victims to these regimes.

One of such Ukrainian translators was Bohdan Kravtsiv, a talented poet, literary critic, critic and bibliographer, without whose work the poetry of Galicia in the 1920s and 1930s "looks like a tree with a torn cone" [3]. For a long time, Bohdan Kravtsiv's poetic and translated works have been removed from the Ukrainian literary process. He appeared on the poetic horizon when the voices of the interned from Ukraine poets of the "Prague School" such as Yurii Darahan, Yurii Lypa, Leonid Mosendz, Yevhen Malanyuk resonated in emigration, when such poets as Sich shooters Vasyl Bobynskyi, Yura Shkrumelyak, Levko Lepkyi and others founded a literary cicle "Mytusa" in Lviv, and Pavlo Tychyna and Maksym Rylskyi spoke loudly about themselves in eastern Ukraine. The son of a Greek Catholic priest, born in 1904 in Boikivshchyna, he studied at a gymnasium and later at Secret Ukrainian University, was far from glorifying the proletarian ideology, and as a result received little attention from either Soviet or emigrant Ukrainian critics. However, the contribution of Bohdan Kravtsiv deserves to finally return in full scope to Ukrainian readers and become a valuable asset to Ukrainian literature. It is equally important to analyze the translation legacy of Bohdan Kravtsiv such as the translation of the biblical Song of Songs [4] and, above all, his collection of translations of Rainer Maria Rilke's Things and Images [5], which can compete with the most prominent Ukrainian translations of the famous German poet and, undoubtedly, will enter the Ukrainian cultural heritage.

\section{Research methods}

Cultural heritage is treated in this paper based on the broad and dynamic understanding of culture. It encompasses the "man-made world of spiritual values, material products of art and social institutions" [6], as well as "a system of values formed in accordance with the living conditions for one's own orientation" [7]. Transitions between national cultures are treated as plausible and inevitable. "An interspatial transition between stable identifications enables the creation of a cultural hybrid, in which there is room for differences without any adopted or established hierarchy" [8].

Theoretically relevant to the proposed study are the issues of the relation between the concepts of multiculturalism, interculturalism and transculturalism defined by a German philosopher and representative of postmodernism Wolfgang Welsch [9], and further developed in this paper.

Ukrainian cultural heritage can be modeled and described in terms of the interaction between the categories of multi-, inter- and transculturalism. In Ukraine, it is formed by the coexistence of different in content and forms ethnic cultures (multicultural aspect), which, despite the differences, under the pressure of social, socioeconomic factors interact 
(intercultural aspect). In addition, there is another dimension - transcultural, which involves not so much mixing elements of different cultures and eliminating the boundaries between national cultures, as the possibility of the existence of a certain culture not only in the context of individual national entities, but also adopting transcultural elements. In particular, it allows considering as part of the Ukrainian cultural heritage the works of all those artists who, due to various life circumstances, were forced to leave their home country and create abroad still being part of its culture.

Among the most important mediators between cultures are translators, who contribute to the intercultural transfer, i.e., a set of "the representation of other culture" [10]. Furthermore, under dictatorship, translation often became almost the only means of preserving and creating a nation, as it was in the hard times in Ukraine, which was repeatedly emphasized in the works of Ukrainian translation scholars R. Zorivchak, M. Novikova, M. Strikha, O. Cherednichenko.

Nonetheless, the personality of a translator has only recently become the subject of special research. The well-known translator I. Levý considers the personality of a translator to be a significant subjective factor in making objective decisions in the translation process [11]. The personality of a translator appears as a translation decision maker and manager in the works by the German translation researcher F. Paepcke [12]. G. Stolze [13] views the background knowledge of translators and their life experience as particularly important. A German translator Wilss attributes even a more significant role to a translator's personality and knowledge [14]. In regards to the framework of the Scopos theory, the importance of taking into account social and professional factors of a translator's activity was emphasized [15]. The so-called 'cultural turn' of the 90s expanded the understanding of translation and the role of a translator in this process, which made cultures, not texts, the object of translation [16], and endowed translation with the social function translators are supposed to perform in accordance with certain social requirements and views [17]. The works of K. Lauber [18], E. Pym [19], and A. Lefevere [20] are devoted to translators' personalities.

Ukrainian researchers, starting with M. Zerov [21], also paid attention to the personality of a translator (Novykova [22], Zorivchak [23], Odrekhivska [24], Savchyn [25], Kolomiyets [26] and others).

The characteristics of a translator are complex and formed by a number of components, among which language is one of the most important. By analogy with the concept of the language personality introduced by V. Vinogradov [27] and developed into an independent field of personality studies by Yu. Karaulov [28], a separate area of studying a translator's personality was developed as part of translation studies [29].

We view the language personality of a literary translator as a multilingual person together with his/her translation activity, influenced by a number of biological, social, psychological, national, historical and political factors.

It appears feasible to model the structure of the language personality of a translator based on the previous research. Yu. Karaulov offers a three-level scheme of the linguistic personality: 1) the verbal-semantic level, which is responsible for the level of language acquisition skills; 2) the cognitive level, which deals with notions, ideas, concepts that form an individual an individual world view of a language personality with a corresponding system of values; 3) the pragmatic level, responsible for motives, goals, interests, guidelines and intentions [30].

The Ukrainian psycholinguist L. Zasiekina outlines the cognitive aspect correlating with language competence and language world view, the emotional component associated with biological, social and psychological emotions, and the motivational component aimed at language goals, motives, guidelines, and intentions [31].

M. Ivanytska applies the experience of previous classifications directly to the structure of the language personality of a translator. Following this researcher in the given paper we 
will distinguish verbal, cognitive and pragmatic-motivational levels of the structure of the language personality of a translator [32]. We will consider the verbal level to be responsible for the innate qualities of a translator - his talent, ability to master languages, gain necessary knowledge and apply it.

From the perception of the world, the accumulated experience of professional activity and social existence, the "inner being of the general" or "general knowledge" [33] of the cognitive level is formed. In the process of socialization, language world view is formed as a dynamic one with the ability to change depending on external or internal circumstances. It is important to emphasize that the individual translator's world view (just like other members' of society) is determined by the national world view and is subject to transcultural influence.

The pragmatic and motivational level of the structure of the linguistic personality is conditioned by the communicative activity needs. Translators' motives can be various - the desire to share their perception and interpretation of foreign works, to acquaint the reader with the masterpieces of other national literatures, to use translation to publish works that are banned in the home country, to promote the national language and literature. In this respect, the pragmatic level correlates with language policy.

The three levels of the structure of a language personality do not have a hierarchical structure, clear boundaries; they interact and are subject to social, political and ideological influences. A translator is a player on the "global translation field" [34] and is forced to play by the rules. This idea is based on the theory of fields by P. Bourdieu, and is formed by three components: field, capital and habitus. The field is a relatively closed and autonomous system of relations that functions independently of other coercion, it is a structured system of places in society and the forces that link them together. The capital is an economic variable (money), as well as cultural (education), human (knowledge, qualities), social (relationships and contacts), symbolic (prestige), which field players use to maintain or strengthen power, status or reputation. Habitus in the interpretation of P. Bourdieu is a disposition or habitual tendencies that determine the behavior of individuals and institutions that are in certain places in the society [35].

In line with the scientific theory of P. Bourdieu, M. Ivanytska treats the UkrainianGerman translation field as "a socio-cultural space that is at the intersection of the corresponding literary polysystems and is formed by multilevel relations among the players of this field, who, possessing a certain capital, interact in order to represent one sociocultural community on the literary market of another" [32]. In a similar German-Ukrainian translation field is presented the personality of the Ukrainian translator Bohdan Kravtsiv and his collection of Ukrainian translations of Rainer Maria Rilke's Things and Images (1947).

The choice of the research methods is determined by the specific features of the scientific problems tackled in this work and consists in the application, apart from general scientific methods (induction and deduction, generalization and modeling), of a number of research strategies: the descriptive and biographical methods in order to highlight the formation of B. Kravtsiv as a public figure, scholar and translator both in Ukraine and in exile; the comparative-typological method, which allowed drawing certain analogies and exploring the individual features of Kravtsiv's translation skills as opposed to other translators'. The methodology of translation studies of B. Kravtsiv's literary translations includes the holistic method (reproduction of the aesthetic integrity of the original work), the structural method (a study of the language personality of B. Kravtsiv as a translator at the verbal, cognitive and pragmatic-motivational levels), as well as the linguostylistic analysis (identification of the specificity of B. Kravtsiv's style as a translator).

\section{Results}


The formation of Bohdan Kravtsiv as a poet, translator, folklorist and bibliographer largely reflects the atmosphere of his time and the fate of many representatives of his generation. He was born in 1904 in the family of a Ukrainian priest in Boikivshchyna. He largely expanded his studies in Lviv with self-education, becoming a Ukrainian studies scholar, an editor, a poet, a critic, testified by his innate flair, good memory, and ability to grasp everything quickly. Kravtsiv began to write poetry in the gymnasium, his first poem being published in 1922. Born in hard times of the Ukrainian liberation struggle and defeat, he himself learned the taste of defeat early, which left an imprint on all his subsequent work. As Yu. Lavrinenko [36] notes, Kratsiv "created his poetry not because of, but in spite of the circumstances and times, as if going against the flow."

The themes of Bohdan Kravtsiv's works were dictated by his difficult life. He wrote about military fights and the will to win (Dzvenyslava collection), family, friendship and allegiance. His writings contain prison motives as a result of his being kept in a Polish prison. Most works are devoted to the theme of homesickness in the emigration (Under the foreign stars). All Kravtsiv's poetry is a reflection of his life, it is his experience gained in prisons, political struggle, and creative activity.

Bohdan Kravtsiv was the chairman of the Galician Society of Ukrainian Nationalist Youth, the editor of many Ukrainian publishers, was imprisoned for his political activities, and wrote his own poems about it. His prison lyric poetry differs from others in that he does not write sad poems, but realistically reproduces all the cruelty of prison life, its violence and abuse of human dignity.

The motif of the road, the Plast journey is the key one in Kravtsiv's work (Ships collection). He was upset by the Galician provincialism, so in many poems there is a theme of movement, progress, which gradually fades during emigration. When his life in German and then in American exile became a continuous journey, he longed for peace and comfort of his home country and wrote the cycles of poetry Glossary, Evergreen.

Throughout his life, Bohdan Kravtsiv was torn between poetry and political struggle. He was convinced that exile poetry alone will not help Ukraine, so he took an active part in the political life of Ukrainian expatriates, published an anthology of the repressed Ukrainian poets, participated in the compilation of The Encyclopedia of Ukrainian Studies, completed and published four volumes of The Complete Edition of the works by T. Shevchenko, which he had started before the war.

Kravtsiv's choice of Rilke had certain mystical features. In his words:

Back after World War I, as a gymnasium student full of aspirations and literary ideas, I was lucky enough to "grab" a strange book on the shelves of one of Lviv bookstores. It was a large collection of poems The Book of Images and its author was already known to me from some printed translations in The Literary-Scientific Bulletin. It was Rainer Maria Rilke [...]. Little did I understand then from the poems collected in this book. But I returned to them again and again, biting into a foreign language, delving deeper and deeper into the splendor of unusual images. And that is why I still remember that moment of joy when someone's good hand handed me - already a college student, a political prisoner sentenced to three years in prison - a book full of deep poetic wisdom and experience Notes of Malta Lawrides Brigg by the same Rainer Maria Rilke [...] [5]

Curiously enough, in 1939, already in political exile, the first books that accidentally fell into his hands were two books of selected poems by R. M. Rilke, as if deliberately bought in order to roam the autumn parks of foreign cities - to recollect and realize the wise but bitter words of the poet from the poem Autumn Day that "The homeless will build no home!"

It seems to me that the years of hostilities, the years of constant danger and uncertainty about tomorrow have made the personality and works of Rainer Maria Rilke somewhat 
closer to suffering and struggling people. The poet, described by Romain Rolland in his diary as "a short, gentle, a little timid, but full of grace, childlike charm and poetry person", seems to us today - when delving into his poetry, notes and letters - a titanic figure from Rodin sculptures [...] [5].

In the future, Rilke continues to chase Kravtsiv. At the end of the war, destiny led Kravtsiv to the German village of Frankenwald.

Living exactly as it was said in one of Rilke's poems, "where the last houses are," with a dozen or two books rescued from a bombed-out dwelling, including The Selected and The Late Poems and The Sonnets to Orpheus, one August day in 1945. I all of sudden began to translate Rilke's poems. What was once dark and incomprehensible now opened up like the flowers in the early morning, and by the winter of that year I had almost three dozen translations [5].

However, in all this mysticism there is certain logic and certain parallels. Kravtsiv was attracted to Rilke not only by his unsurpassed poetry, but also by his similar fate and affection for Ukraine. And it was Kravtsiv who became the poet-translator who first introduced Rilke's poetry to the Ukrainian reader.

Few famous German poets are as connected to Ukraine as Rainer Maria Rilke. And few Ukrainians know that Ukraine, the spiritual world of Ukrainians has significantly influenced the poet's works.

Rainer Maria Rilke (1875-1926), along with Stefan Georg (1868-1933) and Hugo von Hoffmannsthal (1874-1929), is one of three poets who are unanimously considered classics of modern German poetry and whose works have defined an entire epoch of early modernism.

In his early work, Rilke experimented with different styles of his time - naturalism, aesthetics, impressionism and symbolism, and at the same time moved away from them. In the middle of his poetic career, the poet published a number of collections - Das Buch der Bilder [Book of Paintings] (1902/1906), Das Stunden-Buch (1905) and Neue Gedichte [New Poems] (1907-1908). It is no coincidence that the author called the last collection "new" poems. With them he started an innovative genre in early modern poetry - "a thing poem". Influenced by Auguste Rodin and Paul Cézanne, Rilke created the artistic ideal of "concrete speech." In the poems of this period, which often take the form of a sonnet, Rilke approached things like an artist. From Rodin, with whom he befriended in Paris, Rilke inherited a quiet contemplation of nature. From an amorphous-sensitive verse, he moved to a well-formulated thing poem, in which the lyrical self is usually only implicitly present, perceiving, and describing people, objects, animals, or plants. However, "concrete speech" does not imply an objective picture of things at all, but rather the opposite. Thing poems only show that perception is always based on subjective experience, because of which the object and the subject of perception cannot be separated from each other, and the things seen are irreversibly subjectively modified.

Despite the novelty of Rilke's poetry, its author is considered a representative of conservative literary modernism, because his poems meet the formal requirements and are a certain opposition to civilizational modernism. At the same time, conservative modernism itself is in opposition to the artistic avant-garde of the next decade.

In the late period of his poetic career, Rilke published Duineser Elegien and Die Sonette an Orpheus, in which he preferred ancient models of elegy, hymn and sonnet, which he expanded with new forms and themes. Both cycles are represented by mythopoetic poems, which raise the question of the relationship between the self and the world, art and life, death and love, and give abstract, hermetic, and difficult-to-understand answers.

It is clear that it is extremely difficult to translate such poetry. Rilke's personality puts pressure on the translator, causing fear of distorting or inaccurately conveying something. And how can one accurately convey hermetic poetry? How to catch the author's idea, when 
in addition to the form, everything else needs to be guessed? How to evoke in a demanding reader proper associations or reflections on the work of art? It is obvious that without indepth knowledge of life, creative works, stages of becoming a poet, poetic method and features of Rilke's style, the correct translation of his works is hardly possible.

But no less important is the filigree command of the native language, feel for it and the inherent flair for the creation of new, bold and juicy words, understanding the peculiarities of the development of national literatures.

All these qualities belong to the talented poet and translator Bohdan Kravtsiv, who managed to set up a tuning fork on Rilke, to capture his things and paintings, style, symbolism, form and spirit of his poetry.

One of Rilke's characteristic poems is the poem Autumn Day [Herbsttag], written in 1902. This is one of those poetic masterpieces that made Rilke a poet of autumn. No one else was able to convey the idea of the approaching end of human existence by means of the refined and simple 'autumn' metaphor.

Structurally, each of the three stanzas refers to different periods of autumn.

\section{Herbsttag}

Herr, es ist Zeit. Der Sommer war sehr groß.

Leg deinen Schatten auf die Sonnenuhren,

und auf den Fluren lass die Winde los.

The first stanza is about the end of the summer (past tense) and the approach of autumn, which is thematically reflected by the words Schatten, Winde. The imperative conveys the call for autumn, and the reason is simple - es ist Zeit. Addressing God by means of Herr gives the verse a form of a prayer. The flow of time cannot be stopped. This is conveyed by the antithesis of Schatten - Sonnen (uhren) and the arrival of the winds lass die Winde los.

Befiehl den letzten Früchten, voll zu sein;

gib ihnen noch zwei südlichere Tage,

dränge sie zur Vollendung hin, und jage

die letzte Süße in den schweren Wein.

The second stanza semantically reflects fruit ripening. In the form of a prayer there is a request to fill the grapes with the last malt, which symbolizes the last joys of life. Generally, time does not go by, it helps to ripen voll, Vollendung.

Wer jetzt kein Haus hat, baut sich keines mehr.

Wer jetzt allein ist, wird es lange bleiben,

wird wachen, lesen, lange Briefe schreiben

und wird in den Alleen hin und her

unruhig wandern, wenn die Blätter treiben.

The third stanza radically changes the object of observation. It is not autumn nature, but man in the autumn. Syntactic parallelism reinforces the inevitability of the impact of autumn on man. If a house is not built before its arrival, it will not be built at all, if a person was alone, it will remain alone. This state of loneliness will be long and restless.

The theme of maturation organically combines nature and man. The call for the ripening of the fruits of nature is opposed to the false 'ripening' of man, which cannot be corrected later. This is emphasized by the structure of the third stanza, which, unlike the first with a circular rhyme (with an inner rhyme in the second line) and the second with a perfect circular rhyme has an additional line that seems to continue the thought of a walk along a lonely alley when leaves fall from the trees.

The poem emphasizes that it is crucial to build one's own life in time, realize oneself in society, otherwise loneliness, sorrow and constant anxiety await you.

With such metaphors and ambiguity of Rilke's poetry and paradoxically transparent and laconic language, the translator is faced with an almost unrealistic task - to convey by 
means of other language all this rich content and sophisticated form. Let us see if Bohdan Kravtsiv coped with this task.

\section{Осінній день}

То час вже, Господи! Величне ж ти

дав літо нам. Ті соняшні години

вкрий тінню і в поля вітрів пусти.

\section{Плодам останнім стигнути звели; хоч двома ще південнішими днями даруй ось ӥх, щуоб сповнились і тьмяне, тяжке вино солодкістю налий.}

Тим, хто бездомний, дому не звести.

Хто нині сам самотнім він лишиться:

читатиме, писати як не спиться-

листи він буде довгі і брести

алеями з тривожним вихром листя.

In the first stanza, Kravtsiv preserves the imperative mood, which makes it possible to preserve the form of prayer. However, the movement of the appeal to God from the beginning of the stanza somewhat violates the canon of prayer. The translation reproduces the circular rhyme, but the inner rhyme of the second line of the original is lost. It is not entirely appropriate to use the form of соняшні (soniashni) instead of сонячні (soniachni) in the meaning "sunny". It evokes some analogy with a "sunflower". In general, the translation is almost literal.

The second stanza is very well conveyed in terms of content, both imperative address and lexical content. The only thing that somewhat distorts the perception is the shifted stress in двома (two), but it saves the rhythmic structure of the poem.

Similarly, Bohdan Kravtsiv shifts the stress of the word лишиться (will remain) in the third stanza. However, in general, the form and content are conveyed almost flawlessly. And the idea of time which must be properly spent fully correlates with the original. It is not possible for the translator, just like for like Rilke, to concisely list all the activities of a lonely person, whose anxiety he transfers to leaves. However, after reading the translation, the same disturbing feeling of anxiety at the end of the last line remains.

Even more skillfully Bogdan Kravtsiv translates another of Rilke's most famous poems Der Panther, also written in autumn of 1912 and published in the collection Neue Gedichte. The poem is even more densely filled with symbols. In general, Rilke's symbolism is based on detailed observation and perception of things. Such careful contemplation should eliminate any vagueness of perception. Rilke strives for a symbolic perception of all things. That is why his poems are called thing poems. In the poems like Der Panther, the poet goes beyond his observation and the poem becomes "untitled." Feelings or moods no longer come to the fore in it, but it looks like things describe themselves and speak to the reader.

In the poem Der Panther, Rilke chooses the botanical garden Jardin des Plantes with a menagerie as a setting. In 1902-1906 Rilke was in Paris, and among others he visited a botanical garden, where he carefully studied the behavior of predators. It is known from his letters that the poem Der Panther was the result of his own observation of an animal whose living conditions in the menagerie were far from perfect. Rilke as the author does not provide any observations in the poem. The reader focuses solely on the object of observation.

The poem consists of three quatrains written in five-foot iamb. Only the last line is fourfoot. The iamb dynamically conveys the repetitive movements of an animal that moves in an enclosed space. Female stanzas interchange with male ones. The stressed names add 
rhythm to the event "Blick, Vorüber-gehn, Stäbe". As a result of the interaction of poetic size and rhythm, caesuras appear, which draws the reader's attention to the figure and gaze of the animal ,und hinter tausend Stäben / keine Welt”, , in der betäubt / ein großer Wille steht"; ,, und hört im Herzen auf / zu sein “.

\section{Der Panther}

Sein Blick ist vom Vorübergehn der Stäbe

so müd geworden, dass er nichts mehr hält.

Ihm ist, als ob es tausend Stäbe gäbe

und hinter tausend Stäben keine Welt.

The first stanza describes the gaze of an animal that has passed the bars of a cage so many times that its gaze has simply become still, in contrast, the bars move past the panther, run past its gaze no longer able to catch up with this relentless movement. The animal has the feeling that there are infinite bars ("tausend Stäben"), which, as a result of continuous movement, form an enclosed place, behind which the world is not visible ("keine Welt").

Der weiche Gang geschmeidig starker Schritte,

der sich im allerkleinsten Kreise dreht,

ist wie ein Tanz von Kraft um eine Mitte,

in der betäubt ein großer Wille steht.

The second stanza conveys the state of an animal closed in a small space, which, despite the soft gait of its "elastic" legs ("weiche Gang geschmeidig starker Schritte"), goes in circles without any purpose in a small nook ("allerkleinsten Kreis"). Even the majestic dance of power ("Tanz von Kraft") cannot change the nature of the movements that diminish the animal's willpower.

Nur manchmal schiebt der Vorhang der Pupille

sich lautlos auf-. Dann geht ein Bild hinein,

geht durch der Glieder angespannte Stille-

und hört im Herzen auf zu sein.

The third stanza describes the animal's gaze, which it only occasionally raises. Only then, behind the curtain of the eyelid, does it capture some picture. It is then that for a moment the image reaches the nature of the beast ("geht durch der Glieder angespannte Stille"), its heart, but only for a moment, to immediately fade ("hört im Herzen auf").

The poem symbolizes the state of captivity - external and internal, which does not necessarily presuppose the bars. The state of "enclosure" can be the result of social, moral or ethical obstacles that accompany the inner devastation of man. There is no way out for the panther. This is a warning and, at the same time, a call not to give up under the pressure of external circumstances, so as not to destroy the inner world.

Bohdan Kravtsiv works on the translation as a real translator following the principle "Do no harm!" He fully preserves the structure of the poem, its size, the interchange of female and male rhymes. Just like Rilke, he only once uses the name panther in the title to refer to the animal, does not transliterate the name of the botanical garden, only spells Paris in Ukrainian.

\section{Пантера \\ (B Jardin des Plantes, Париж)}

Від мимоходу штаб ій погляд кволо

утомою осмерк, осліп, як тьма.

Їй так, мов итаби тисяччю навколо

і поза ними світу вже нема.

Пруживих ніг хода м'яка, щзо метко сотає кіл щзолишнайменших пліть, мов танець сили вколо осередка, 
де велич-воля очманіла спить.

\section{Лиш інколи зінищь завіса має \\ нечутно вгору. Зрине образ їм, \\ нап'яту тишу м'язів прошибає - \\ і гасне в сериі хижім і тьмянім.}

He manages to preserve the dynamics of the poetry both by its size and by the appropriate caesuras ("i поза ними / світу вже нема; і гасне / в сериі хижім і тьмянім"). Preserved personification of the bars ("мимоходу штаб") adds rhythms to the story and emphasizes the passivity of the animal. His gaze is personified just like in the original ("погляд кволо утомою осмерк"). The alliteration of $\mathrm{g}$ in the original ("Gang, geschmeidig") is replaced with the alliteration of $\mathrm{m}$ ("м'яка, метко") by Kravtsiv. Both the author and the translator clearly record the elegance of the animal's movements which are inconsistent with its unnatural state. The minimal space in which the beast is enclosed is successfully conveyed: "allerkleinsten" - "щолишнайменших". Kravtsiv reinforces the meaning of "Wille" [will] by alliterated "велич-воля". The paradox of the original "betäubt ein großer Wille" is also well conveyed by "велич-воля очманіла спить".

For the metaphor "der Vorhang der Pupille" Bohdan Kravtsiv finds the equivalent of "зінииь завіса", which, just like the original conveys the apathy of the beast driven into the cage. The translator successfully reproduces the further personification of "Dann geht ein Bild hinein" as "Зрине образ".

With the help of the metaphor "cepue" [heart] Kravtsiv literally translates Rilke, who uses this metaphor to denote a whole being, in which for a moment what is seen immediately fades as the real existence of the being itself fades. The constant movement of the animal still gives hope for its possible release, but the last line ruins that hope.

A brief analysis of only two Bohdan Kravtsiv's translations from Rilke testifies to his mastery. The advantages of the translator include the wish to convey the content and form of the original as accurately as possible, to reproduce its imagery, symbolism and mood. On the example of the analyzed translations of Rilke's poems performed by Bohdan Kravtsiv, we can see that poetry can and should be translated.

Bohdan Kravtsiv was the first Ukrainian poet to translate Rainer Maria Rilke's poetry, but far being the last. Although Rilke still remains little known in Ukraine, such prominent Ukrainian poets (translators) as M. Zerov, M. Bazhan, Y. Klen, M. Orest, M. Yohansen, O. Lutskyi, L. Mosendz, O Zuievskyi and others contributed to the translation of his poetry. Until recently, Bohdan Kravtsiv was the only author of the collection of Rilke's translations, until in 2012 another collection was published by the Lybid publishing house in Kyiv - Rainer Maria Rilke. One Hundred Poems Translated by Moses Fishbein. However, very few poets managed to comprehend the depth of Rilke's poetry and convey its unsurpassed syncretism of form and content.

It is interesting to compare Kravtsiv's translations with the translations performed by other poets. For example, let us consider the famous poem by Rilke Autumn translated by Kravtsiv and Stus.

Rilke wrote the poem Autumn in 1912. The poem consists of four stanzas - one tercet and three distichs, written in a five-foot iamb. Four female rhymes interchange with five male rhymes. Of the two circular rhymes, the first contains an unrhymed second line in the first stanza (abc ca de ed).

The first line describes the falling leaves. The second line takes us to remote gardens that have grown to the sky and have to shed their leaves in autumn. In the next line, the poet uses the metaphor of resistance (or most likely frustration or desperation) to represent the unwilling fall of these leaves. 
The second stanza conveys the mood of loneliness, in which "heavy earth falls at night". The leaves fall and the earth falls. In the same way we will all fall - both this hand and the other. Such a fate awaits everyone - says the third stanza. Time is unstoppable, and nothing can affect its course.

The sad mood of the former stanzas adds optimism to the latter. Everything falls not into the abyss, and not into obscurity, but into the gentle hands of the One, the One who makes any fall soft and who can intervene in the flow of time.

Rilke's metaphors are successfully conveyed by the translations of both Kravtsiv and Stus. Heavenly gardens symbolize paradise. The fall of the withered leaves indicates the ephemerality of earthly existence. Kravtsiv almost literally conveys the meaning of the original, while Stus resorts to additional definitions (рясне небо, останній жар) and creates new metaphors (розприскує земля останній жар, і нам опасти вже своя черга, губишся в ваганні). Kravtsiv is better at endering the "negative" fall of the leaves (cnadaє заперечливо з туману) than Stus (Воно спадає, сповнене досади). Both translators successfully render the mood of fall, but not decline. In both poems the religious motive is preserved, in particular lexically (сади далекі в небі, небесного рясного саду, Один, Він, Госnодb). However, even in this case, Kravtsiv adheres to the original and does not use direct nominations to denote God as Stus does.

The iambic construction of the stanza in the original and in both translations rhythmically imitates the fall of the leaves and brings this process to a climax in the sixth line. In case with Kravtsiv, this is again more concise and literal - Ми всі падем, while Stus offers his vision of Rilk's painting: I нам опасти вже своя черга.

The inevitability of the fall conveys the parallelism of the sixth line, which is preserved by Kravtsiv (Ми всі падем. Впаде рука ия в тлінь), but lost by Stus. The fall symbolizes here the process of aging, the inevitable end.

The antithesis of the fall is the last stanza mentioning God (Один, Він, Госnодь), who not only saves from the fall (це падання так ніжно держить Він (Kravtsiv), все впале милосердно зберіга (Stus)), but also takes care of the resurrection.

Despite the skillfulness of both translations, Kravtsiv's version seems more successful due to the greater correspondence to the original, a more accurate transfer of its content and form.

\section{Discussion}

Bohdan Kravtsiv's translations were not widely discussed in translation criticism. In Soviet translation studies, Ukrainian authors in exile rarely had positive reviews or remained silent at all. The diaspora critics such as Yu. Lavrinenko, E. Malanyuk, O. Tarnavsky, B. Boichuk, B. Rubchak and others considered first of all Kravtsiv's work as a poet. There is a noticeable interest in his work in independent Ukraine (I. Vasylyshyn, T. Salyha). However, the poet's translation work is mentioned only sporadically and without any analysis of the quality of translations. But certain parallels to translation analysis are evidenced by the literary one.

The critics are quite positive about Kravtsiv's poetic works, although they distinguish between more or less successful poetic attempts. M. Rylskyi's strong influence is seen in the early poetry by Kravtsiv. Kravtsiv himself considered early Tychyna, then Rylskyi and M. Zerov to be his teachers. Rilke was an important figure for him throughout his life. According to $\mathrm{Yu}$. Lavrinenko, Kravtsiv was "split between Kamena and the fight" [36]. It was his political activity that distracted him from fully serving Kamena, the goddess of poetry. And poetry, as we know, does not tolerate it. And the remoteness from the home land, its live speech also contributed to the fact that the poet's language eventually moved away from the norms of the Ukrainian literary language. 
Despite the generally positive assessment of Kravtsiv's translation of the biblical Song of Songs given by Yevhen Malanyuk, the critic criticizes the poetic form of the rendition, believing that a prose translation would have been more appropriate. He attributes the successful places in the translation primarily to Kravtsiv's poetic skills.

The intuition of the poet, the son of the mountainous Galicia, happily directed his imagination towards the pastoral Hutsul coleur local, to the colorful "kolomyika" world of the blooming Carpathian "rain orchid". It is present in a transparent light shadow on the background of the biblical poem, neither scorched by our sun nor by our passion [37].

Malanyuk believes that Kravtsiv's translation managed to get closer to the 'spirit' of the original, and Kravtsiv's contribution to the translation of Song of Songs can be compared to what I. Kotlyarevsky did with Virigil's Aeneid. At the same time, he criticizes Kravtsiv for archaically shortened adjectives and a few clumsy wordings.

Bohdan Boichuk believes that Kravtsiv's style is closely related with his balanced, thoughtful personality and classicism is natural for him.

Starting with the consonance with Mykola Zerov, who called for a return to the sources of Western traditions [...], Kravtsiv with each passing year more and more turns away from the Zerov's track, so that in the poems of Glossary to go his own way in the opposite direction (towards the sources of Ukrainian traditions). Bohdan Kravtsiv is an 'internal' poet who prefers brevity and ellipsis [...] rather than external overstatement and expansiveness [...] [38].

Just like his mentor Rilke, Kravtsiv prefers to leave a lot between the lines so that the reader has room for his/her imagination. Boichuk emphasizes that "the elegant sophistication of the form and richness of Kravtsiv's poetic vocabulary were probably of historical significance in the development of the contemporary for him literature in Western Ukraine" [38].

Bohdan Rubchak discusses Kravtsiv's works in an extensive paper. He criticizes him for sometimes false images and praises him for metonymic transfers when it comes to the figurative aspect of Kravtsiv's poetry [39] emphasizes Kravtsiv's more sophisticated sonnet technique, calling his collection of sonnets Glossary a masterpiece, which is also relevant for the poetic translation of Rilke. Rubchak considers Kravtsiv a master of the use of Ukrainian mythology. This also brings him closer to Rilke, who loved Ukrainian mythology. T. Salyha notes that the fate of Bohdan Kravtsiv is similar to the biographical fate of Rilke, who was born in Prague, lived in Germany, France, Spain, Austria, Sweden, Italy, Russia and Ukraine. "From the latter - from my homeland - Rilke was inspired and fascinated by the vast spaces as well as directness and folklore depth of the people", said Kravtsiv [5].

\section{Conclusion}

Bohdan Kravtsiv has undeservedly remained in the shadow of other Ukrainian poets for a long time. Tychyna, Rylskyi, and Zerov had a significant influence on his formation as a poet. In addition, due to favourable life circumstances, the poetry of Rainer Maria Rilke chased Kravtsiv and was ingrained in his work. The poet had absorbed the Ukrainian spirit, language and culture since his childhood. Throughout his life he was forced to change his place of residence several times, which also influenced the formation of his personality and creative work. However, it did not prevent him from remaining faithful to his roots, traditions and enriching Ukrainian culture outside Ukraine.

The innate poetic flair, strong character, leadership qualities contributed to the formation of the personality of Bohdan Kravtsiv, in particular, as a translator. He began his literary and political activities early. Difficult life circumstances did not break Kravtsiv. He 
continued to gain experience under any circumstances, enriching his inner world, expanding thematically and formally his poetic palette.

The need and desire to be useful to his people gave him strength in exile, forced to combine poetic activity with political, editorial, literary and bibliographic.

Bohdan Kravtsiv's poetic legacy has received fair attention in literature studies. However, his translation work still needs a separate comprehensive study. His translations of Rainer Maria Rilke testify to Kravtsiv's deep understanding of the poet, remarkable translation skills, compliance with the classical canons of translation and the successful transfer of both the form and content of the original work.

\section{References}

1. I. Franko, Collection of works in 50 volumes, 26, 307-316 (1980)

2. R. Zorivchak, Inozemna Philologia 124, 116-131 (2014)

3. T. Salyha, I. Vasylyshyn (Eds.), Under native and strangers' stars (Svit, Lviv, 2018)

4. B. Kravtsiv, Song of Songs (Nakladom O. Mykytky-Stetsyshyn, 1935)

5. B. Kravtsiv, Things and Images: selected poetry (translations of R. M. Rilke) (Chas, Nuremberg, 1947)

6. A. Nünning, Vielfalt der Kulturbegriffe (2009). URL:

https://www.bpb.de/gesellschaft/\%20kultur/kulturelle-bildung/59917/kulturbegriffe

7. G. Auernheimer, Kultur. Ident., 80-105 (1991)

8. D. Bachmann-Medick, Cultural Turns. Neuorientierungen in den Kulturwissenschaften (Rowohlt, Reinbek b. Hamburg, 2010)

9. W. Welsch, Hybridkultur: Medien, Netze, Künste, 67-90 (1997)

10. D. Bachmann-Medick (Ed.), Übersetzung als Repräsentation fremder Kulturen (Schmidt, Berlin, 1997)

11. J. Levý, To Honor Roman Jacobson. Ess. on the occ. of his $70^{\text {th }}$ b-day. 11 th october 1966 2, 1171-1182 (1967)

12. F. Paepcke, F. Übersetzungswiss., 112-119 (1971)

13. R. Stolze, Grundlagen der Textübersetzung (Groos, Heidelberg, 1982)

14. W. Wilss, Translation and Interpreting in the $20^{\text {th }}$ Century. Focus on German (John Benjamins, Amsterdam/Philadelphia, 1982)

15. Ch. Nord, Textanalyse und Übersetzen. Theoretische Grundlagen, Methode und didaktische Anwendung einer übersetzungsrelevanten Textanalyse (Groos, Heidelberg, 1988)

16. S. Bassnett, A. Lefevere (Eds.), Translation, History and Culture (Pinter, London, 1990)

17. G. Toury, The Transl. St. Reader, 198-211 (1978)

18. C. Lauber, Selbstporträts zum soziologischen Profil von Literaturübersetzern aus dem Französischen (Narr, Tübingen, 1996)

19. A. Pym, Negotiating the frontier translators and intercultures in Hispanic history (St. Jerome Publ., Brooklands, Manchester, 2000)

20. A. Lefevere, Translation, rewriting and the manipulation of literary fame (Rouledge, London \& New York, 1992)

21. M. Zerov, New Ukrainian literature: a historical essay (Instytut literatury, Munich, 1960)

22. M. Novykova, Theory and practice of translation 17, 98-107 (1991)

23. R. Zorivchak, Ivan Franko as a translator and translation scholar. URL: https://kameniar.lnu.edu.ua/?p=5235

24. I. Odrekhivska, Language and conceptual world view 26 (2), 365-368 (2009). 
25. V. Savchyn, Mykola Lukash's innovation in the history of Ukrainian literary translation: a dissertation (Kyiv, 2006)

26. L. Kolomiyets, Ukrainian literary translation and translators of the 1920s and 1930s: materials for the course "History of Translation" (VPC Kyivskyi universytet, Kyiv, 2013)

27. V. Vinogradov, About fiction (Nauka, Moscow / Leningrad, 1930)

28. Yu. N. Karaulov, Russian language and language personality (Izdatelstvo LKI, Moscow, 1987)

29. L. A. Dolbunova, Tradition and innovation in humanities research, 116-118 (2002)

30. Yu. N. Karaulov, E. V. Krasilnikova, Language and personality, 3-11 (1989)

31. L. V. Zasiekina, Social psychology 5 (25), 82-90 (2007)

32. M. Ivanytska, The personality of the translator in the Ukrainian-German literary relations (Knyhy - XXI, Chernivtsi, 2015)

33. H.-G. Gadamer, Wahrheit und Methode. Bd. 2. Ergänzungen (Mohr, Tübingen, 1993)

34. N. Bachleitner, M. Wolf (Eds.), Streifzüge im translatorischen Feld. Zur Soziologie der literarischen Übersetzung im deutschsprachigen Raum (LIT, Vienna, 2010)

35. P. Bourdieu, HBK of Th. and Res. for the Soc. of Ed., 241-258 (1986)

36. Yu. Lavrinenko, Modernity. Munich, 5, 28-36 (1967)

37. Ye. Malanyuk, Under native and strangers' stars, 541-542 (2018)

38. B. Boichuk, Under native and strangers' stars, 555-562 (2018)

39. B. Rubchak, Under native and strangers' stars, 562-580 (2018) 